\title{
合成性フェロモン剤（ヨトウコンーS）による エンドウのシロイチモジョトウの防除効果
}

\author{
東 勝千代・矢野貞彦・野畑昭弘* - 西山忠雄** \\ (和歌山県農業試験場 $・ *$ 日高農業改良普及所・**和歌山いなみ町農業協同組合)
}

エンドウのシロイチモジヨトウに対する合成性フェ ロモン剂 (ヨトウコンーS) の交信擋乱による防除試験 については，本報第 32 号で報告した。

和歌山県では, シロイチモジヨトウの発生・被害が 問題となる夏まきエンドウは，気象的立地条件を活か した海岸段丘地で主に栽培されている。このような傾 斜地では, 一般に性フェロモン郕の効果は低いとされ ている。そこで, 本県での実用化を図るために, 緩傾 斜地で防除試験を行った。

\section{試験方法}

試験は, 日高郡印南町（法経豆坂団地・畑地総合開 発地）で行った。フェロモンディスペンサー（プラス チックチューブ中に Z $9 \mathrm{E} \mathrm{12-14：Acと} \mathrm{OHの}$ $7: 3$ の混合物を $80 \mathrm{mg} / 20 \mathrm{~cm}$ 封入, 以下性フェロ モン区と呼ぶ）処理地域の概略は第 1 図に示した。全 体の勾配は $3 \%$, 総面積は 17 ha で, うち, エンドウは 10.7 ha $(63 \%)$ に作付された。エンドウのは種は 8 月 8 日〜 9 月 10 日に行われた。は種後 $3 \sim 4$ 週間は八ト 害の防止や虫媒ウイルス防除のために，防風ネットま たは寒冷紗でトンネル状に被覆された。

フェロモンディスペンサーを 1990 年 8 月 10 日に 150 本 $/ 10 \mathrm{a}$ を長さ $60 \mathrm{~cm}$ の竹または針金の先端に 2 本/本ずつ着けて，均等に設置した。なお，未作付ほ 場では $2 \sim 3$ か所に固めて置き，作付と同時に均等に 設置した。対照無処理（以下無処理地区と呼ぶ）は, エンドウのは種期が性フェロモン区とほぼ同時期の同 町印南及び山口地区を選んだ。両区間の距離は, 直線 で1.2〜2.2 kmであった。

調査は, フェロモンディスペンサー設置後, 両区と もほぼ 10 日間隔で，1 カ所 25 株ずつ 2 力所/筆の被 害株, 寄生虫数を調べた。なお，性フェロモン区は地 形間の効果差を見るために, 上段, 中段, 下段に分け て行った。なお，各段の面積は $2 \sim 3$ ha（100 m $\times$ 200〜300 m) であった(第 1 図)。また, フェロモント ラップを両区 1 力所ずつ 7 月 5 日に設置して, 雄成虫 の誘殺推移を調査した。薬剤散布は農家の自主性に任
せた。

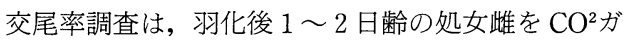
スで麻酔し，翅の基部を約 $30 \mathrm{~cm}$ のテトロンゴース糸 で結束して，各区 60〜120 頭のつなぎ雌を夕方放飼し て翌朝回収し，解剖して交尾の有無を調べた。第 1 回 目 9 月 10 日は地上 $50 \mathrm{~cm}$, 第 2 回目 10 月 10 日は地上 $50 \mathrm{~cm}$ と $150 \mathrm{~cm}$ の位置にセットした。

\section{結果及び考察}

フェロモントラップでのシロイチモジヨトウ雄成虫 の誘殺は，無処理区ではトラップ設置後から見られ， 10 月中旬に大きなピークを示す誘殺推移を示した（第 2 図)。性フェロモン区はトラップ設置後から 8 月 8 日 までの誘殺は 206 頭で無処理区の 2.5 倍であったが, 性フェロモン処理後ほとんど誘殺されず， 8 月 6 半旬 1 頭, 10 月 3 半旬 2 頭が誘殺されたのみであった。

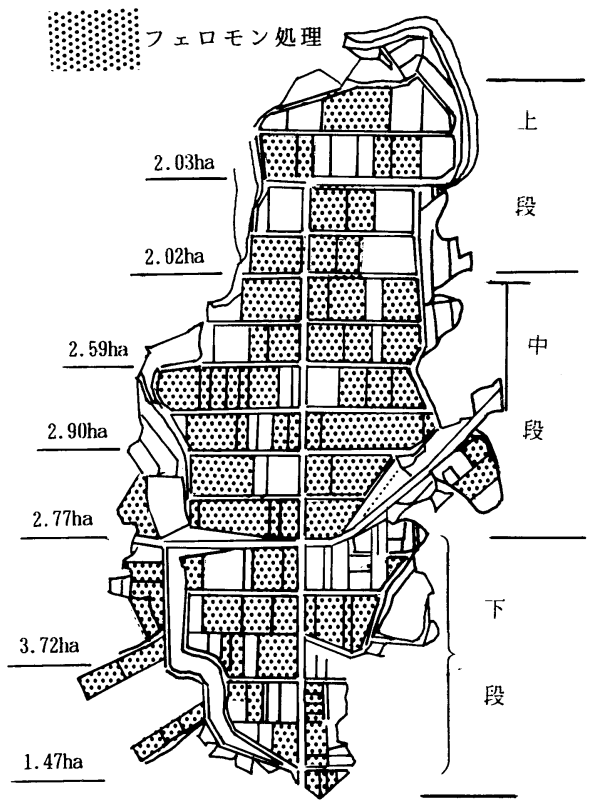

第 1 図 フェロモンディスペンサー処理集落の概略図

Katutiyo AzUMA, Sadahiko YANO,Akihiro NoBAtA* and Tadao NiSIYAMA** (Wakayama Pref.Agr.Exp. Sta. , *Wakayama Hidaka Agr.Ext.Office, ${ }^{* *}$ Wakayama Inami Agr.Co-op.) : Control of the beet armyworm, Spodoptera exigua $\mathrm{H}$. , using synthetic sex pheromone. 


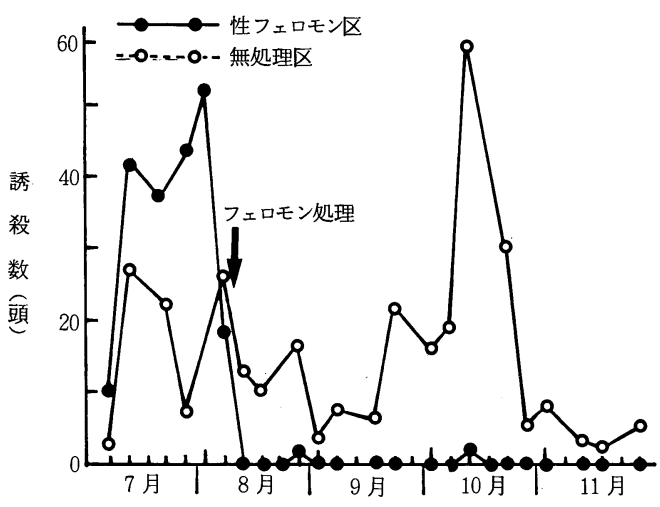

第 2 図 フェロモントラップによる雄成虫の誘殺推移

つなぎ雌の交尾率は，無処理区では第 1 回 $92.6 \%$, 第 2 回目は地上 $50 \mathrm{~cm}$ で $84.2 \%, 150 \mathrm{~cm}$ では $100 \%$ であった。性フェロモン区は第 1 回，第 2 回とも全く 交尾が認めらず，雌雄の交信錯乱による高い交尾阻害 が認めれた（第 1 表）。

第 1 表 つなぎ雌の交尾率調査

\begin{tabular}{|c|c|c|c|c|c|c|}
\hline \multirow[b]{2}{*}{ 処 理 } & \multicolumn{3}{|c|}{ 第 1 回 } & \multicolumn{3}{|c|}{ 第 2 回 } \\
\hline & 高さ & $\begin{array}{l}\text { つな } \\
\text { ぎ数 }\end{array}$ & 交尾率 & 高さ & $\begin{array}{l}\text { つな } \\
\text { ぎ数 }\end{array}$ & 交尾率 \\
\hline $\begin{array}{l}\text { フェロモン } \\
\text { 処理 }\end{array}$ & $0.5 \mathrm{~m}$ & 52頭 & $0 \%$ & $\begin{array}{l}0.5 \mathrm{~m} \\
1.5\end{array}$ & $\begin{array}{l}30 \text { 頭 } \\
30\end{array}$ & $\begin{array}{l}0 \% \\
0\end{array}$ \\
\hline 無処理区 & 0.5 & 55 & 92.6 & $\begin{array}{l}0.5 \\
1.5\end{array}$ & $\begin{array}{l}19 \\
19\end{array}$ & $\begin{array}{r}84.2 \\
100.0\end{array}$ \\
\hline
\end{tabular}

a)つなぎ雌放飼日第 1 回 9 月 10 日，第 2 回10月10日

エンドウのは種時期を 8 月 2 日〜 20 日と 8 月 30 日 〜 月 10 日に大別するとシロイチモジヨトウの発生 被害は第 3 図に示した通りである。エンドウの被害は 発芽間もない複葉展開時からみられ, 被害株率は無処 理区では，それぞれ 79\%，65\%で最高となり，その時 の幼虫生息数は 10 株当り 30.1 頭, 8.6 頭で, は種時期 の早いグループで発生被害が多かった。1989 年 (本報 第 32 号，87 項）とは逆の結果を示した。性フェロモン 区の被害株率は，それぞれ $2.3 \% ， 0.4 \%$ て生息数は 1.8 頭, 0.1 頭で, 被害株率は無処理区の $1 / 30 \sim 1 /$ 100，幼虫生息数では $1 / 16 〜 1 / 80$ 以下であった。

性フェロモン区の地形上から区分した各段別の防除 効果を第 4 図に示した。各段で最も多く被害を認めた 時期の被害株率は，上段，3.2\%，中段 $2.0 \%$ ，下段 $1.6 \%$,生息数は 10 株当りそれぞれ 2.9 頭, 2.3 頭, 0.1

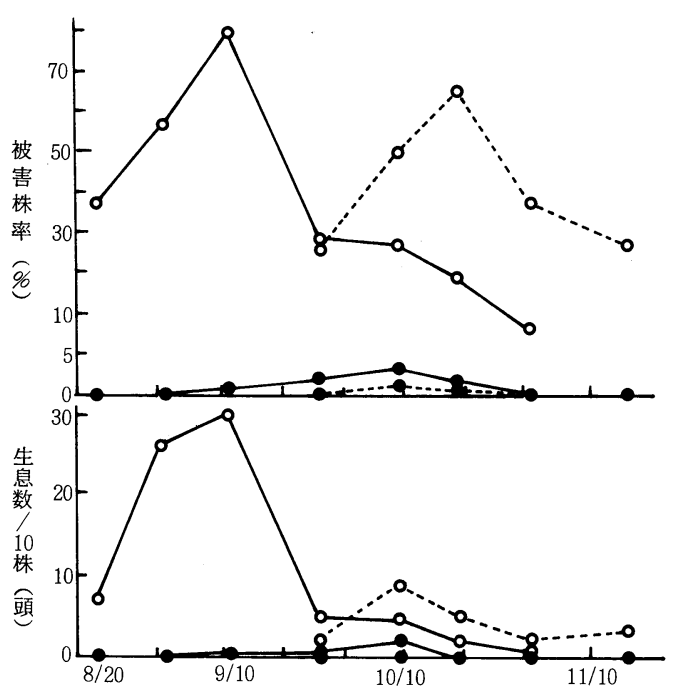

第 3 図 エンドウにおけるシロイチモジョトウの 発生・被害推移

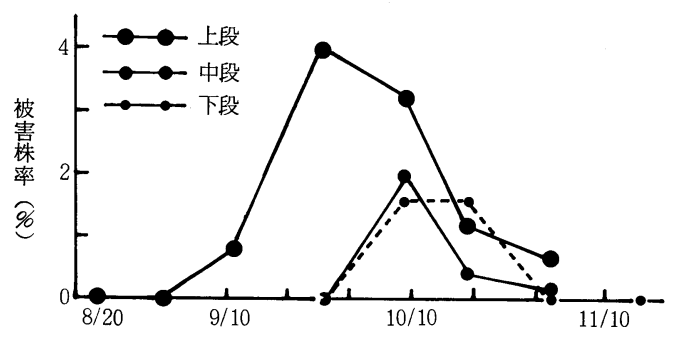

第 4 図処理ほ場の段別被害推移

頭で, 性フェロモンは上段から下段の方に流れたため か，発生は少ないなりにも上段から下段になるにつれ て発生被害は少なくなる傾向がみられた。しかし，こ の程度の差であれば実用上問題はないものと考える。

以上の結果, $3 \%$ 勾配の傾斜地 $17 \mathrm{ha}$, うち処理面積 10.7 ha で, 性フェロモン処理と被覆資材や薬剤散布 との併用で, 顕著な密度抑制効果が得られた。また, ほ場の高低での防除効果は上段＜中段<下段の順で あったが，各段間に大差は見られなかった。したがっ て，このような生産団地であれば，性フェロモン剤の 処理面積率を高め寒冷紗被覆との併用処理で, シロイ チモジヨトウの密度抑制手法として十分活用できると 考える。 